\title{
Sexually transmitted infections - laboratory diagnosis
}

\author{
Participants: \\ (D) Maurício Hachul \\ Marcus Vinícius Verardo de Medeiros ${ }^{1}$ \\ (iD) Ricardo Simões ${ }^{1}$ \\ Wanderley Marques Bernardo² \\ Contact:wmbernardo@usp.br
}

Final version: April $2^{\text {nd }}, 2019$

1. Brazilian Society of Urology, São Paulo, SP, Brasil 2. Brazilian Medical Association, São Paulo, SP, Brasil

The Guidelines Project, an initiative of the Brazilian Medical Association, aims to combine information from the medical field in order to standardize producers to assist the reasoning and decision-making of doctors.

The information provided through this project must be assessed and criticized by the physician responsible for the conduct that will be adopted, depending on the conditions and the clinical status of each patient.

The purpose of this guideline is to present recommendations that may assist in the diagnosis of patients with sexually transmitted infections. For this purpose, a review of the literature was performed using the appropriate descriptors and using the PICO strategy (Syphilis, Urethritis, Genital Ulcers, HPV, diagnostic test, quick test, laboratory methods, etiologic agents). The literature search was conducted without restrictions regarding the year of publication or language, in the MEDLINE database, resulting in 52 studies to answer the clinical questions. Details of the methodology can be found in Annex I.

\section{RESULTS}

What are the tests used for the diagnosis of syphilis?

The choice of test for the diagnosis of syphilis depends on the stage of the disease and its clinical presentation. In individuals with ulcerated lesions, bullous lesions, condylomas, or injuries related to congenital syphilis, specific methodologies that al- low for the direct detection of Treponema pallidum in the sample collected from the lesion are preferable because they are considered definitive tests. However, such exams are not easily accessible. Besides relying on experienced microscopist, they depend on the number of treponemas existing in the sample and is therefore not a feasible test after the healing of the lesions of primary and/or secondary syphilis. The darkfield microscopy, traditionally used to detect $T$. pallidum, presents values of sensitivity that range from $70 \%$ to $85 \%$ and its specificity can reach $96 \%$. Alternatives also include microscopy after staining by the Fontana-Tribondeaux, Giemsa, or Levaditi methods, besides the use of direct immunofluorescence (DFA-TP - Direct Fluorescent antibody Treponema pallidum) and PCR (Polymerase Chain Reaction) ${ }^{1}(\mathrm{~A})^{2}$ $(\mathrm{C})^{3}$ (B). In DFA-TP, the treponemas present in the sample are identified through the use of anti-Treponema pallidum antibodies, marked with fluorescein isothiocyanate. This technique has the advantage of presenting higher values of sensitivity and specificity in comparison with darkfield microscopy. Among 
all methods of molecular biology, polymerase chain reaction (PCR) has been the most frequently used for the laboratory diagnosis of STIs. A systematic review that included 46 studies found that the use of PCR for the diagnosis of syphilis presented higher values of sensitivity in the identification of T. pallidum in ulcerated lesions of primary syphilis and anal injuries (78.4\% and 95\%, respectively). It was also possible to verify that the detection of $T$. pallidum in blood samples presented higher values of sensitivity in congenital syphilis (83.0\%) and in secondary syphilis $(52.2 \%)^{4}(\mathrm{~A})$. In addition to presenting high accuracy, it can be used in various biological materials such as serum, blood, cerebrospinal fluid, amniotic fluid, and tissues. However, the technique is not routinely used due to its high cost and methodological difficulties.

Serological tests are the most commonly used for the tracking, indirect diagnosis, and monitoring of treatment, and its accuracy varies according to its intended use. There are two different types of tests employed, in general, in this order: one for identifying individuals with a possible infection, known as a nontreponemal test, followed by a second confirmatory test, known as a treponemal test. However, the order of the tests may be at the discretion of the health service. The first is directed to nontreponemal antibodies that bind to micellar structures formed from a suspension containing anticardiolipin antibodies, cholesterol, and lecithin. The tests most commonly used are the RPR - Rapid Plasma Reagin, VDRL - Venereal Disease Research Laboratory, USR - Unheated Serum Reagin, and Trust - Toluidine Red Unheated Serum Test, which detect immunoglobulin M and G (IgG and IgM) anti-T. Pallidum antibodies against the lipid material released by the cells damaged by the infection. They are based on the flocculation method, and its results are released in the form of titles, varying according to the activity of the disease, thus providing a quantitative result that allows for the control over the response to the treatment ${ }^{5.6}(\mathrm{~B})$. The persistence of low titles in patients treated adequately is called a serological scar, which may persist for many years ${ }^{7}$ (D). Results of nontreponemal tests may not become positive in cases of primary syphilis (usually, they become positive between five and six weeks after the infection and between two and three weeks after the onset of chancres). In addition, a gradual reduction of titles can happen even without therapy, and some patients may even become nonresponsive (false-negative results) ${ }^{8}$ (B). False-negative results can also occur when there is an excess of antibodies in the serum samples tested, a phenomenon known as hook effect. Another disadvantage regards false-positive results that occur in $2 \%$ to $5 \%$ of cases; since the reaction is not specific, a cross-reaction with other infectious diseases, pregnancy, autoimmune diseases, and chronic infections can occur ${ }^{9}$ (C).

After the treatment of immunocompetent individuals, nontreponemal tests become non-reactive within six months. However, approximately $20 \%$ of infected individuals remain with positive titles ${ }^{10}(\mathrm{~B})$.

Treponemal tests, on the other hand, are specific to detect antibodies against cell components of T. pallidum and include the FTA-ABS - fluorescent treponemal antibody adsorbed, TPPA - Treponema pallidum Particle Agglutination, MHA-TP - Microhaemagglutination assay for antibodies to T. pallidum, TPHA - T. pallidum haemagglutination, and the ECL - immunological test with electrochemiluminescence. These tests require trained personnel, are more expensive and technically more complex than nontreponemal tests. Thus, other methodologies that are cheaper, easier to perform and automated are represented by the EIA - enzyme immunoassay and Western-blot $t^{11.12}$ (C). Immunoassay techniques (EIA) use plates coated with antigen (extract of T. pallidum or recombinant proteins). The serum is placed in contact with these components, and the presence of antibodies is evidenced using a marked anti-human antibody (anti IgG or IgM). This technique has the advantage of being automated, which allows the study of many samples simultaneously, eliminating the subjective reading of the hemagglutination and immunofluorescence techniques, since it is performed in a spectrophotometer. Regardless of the type of treponemal test, these tend to be qualitative and usually remain positive throughout life, despite the successful therapy, and cannot be used to make a distinction between an active infection of a previously treated one. Therefore, they do not help in the evaluation of the response to treatment. These tests are used as a confirmation after a positive result in a nontreponemal test. With the latest technology, there are also rapid diagnostic tests for syphilis, known as POC - pointof-care. They are easy to perform, with no need for the use of equipment, and results are available in approximately 10 to 15 minutes. Like other treponemal tests, it has some limitations, since they are incapable of distinguishing between a recent infection and a previously treated one. 
How are the rapid tests conducted for the diagnosis of syphilis?

The objective of rapid diagnostic tests for sexually transmitted infections, known as POC - point of care is to detect antibodies or antigens ${ }^{13}$ (D). These tests allow executing, obtaining, and interpreting results quickly, easily, cost-effectively, and accurately with a minimum volume of blood collected by venipuncture or digital pulp ${ }^{14,15}(B)^{16}(\mathrm{~A})$. They can also be performed with samples of serum or plasma. Several tests were evaluated in different clinical and community contexts; in Brasil, the rapid tests available for the diagnosis of syphilis use the methodological principle of lateral flow immunochromatography and dual platform migration ${ }^{17}$ (B). As treponemal tests, they presented as their main limitation the inability to distinguish between an active infection and a previous or previously treated infection, which may lead to the overdiagnosis and, consequently, to overtreatment. These tests play an important role in clinical situations in which the delay in the diagnosis becomes a problem, such as during gestation (the delay or absence of treatment poses significant risks to the fetus, completely outweighing the risks of overtreatment for the mother $)^{18}$ (A). A study analyzing the accuracy of rapid testing for T. pallidum found, in a total of 1,323 patients, results comparable to those obtained with the treponemal test TPPA, with values of sensitivity and specificity of $87.2 \%$ (95\% CI: 84 to 89.9 ) and $94.4 \%$ (95\% CI: 92.6 to 95.8 ), respectively for the test performed from samples collected by digital puncture. ${ }^{19}$ (B).

\section{What are the laboratory diagnostic methods} for urethritis?

Urethritis is characterized by an inflammation of the urethra that may or may not have an infectious origin. Eventually asymptomatic, when it manifests symptoms there can be the presence of urethral discharge, dysuria, urethral burning or pruritus, which are usually associated with the causative agent. However, the determination of etiology based only on symptoms or physical examination is not considered reliable. They have a strong association with sexually transmitted infections, and can be classified as gonococcal, when caused by Neisseria gonorrhea, and non-gonococcal, when associated with Chlamydia trachomatis or other etiologic agents represented by Mycoplasma genitalium, Neisseria meningitides, herpes simplex virus, Treponema pallidum, Trichomonas vaginalis, Ureaplasma urealyticum, adenoviruses, and Candida $\mathrm{sp}^{20}$ (C). The trauma of the urethra is the less common cause of urethritis but can occur with intermittent catheterization or after urethral instrumentation or the insertion of a foreign body. The clinical suspicion is triggered when any sexually active individual presents symptoms consistent with urethritis, including itching, urethral discharge, or dysuria. Women with urethritis and usually have cervicitis and can manifest abnormal uterine bleeding, bleeding after intercourse, and changes in vaginal content.

The diagnosis of urethritis is mainly based on clinical signs and symptoms that are accessed by means of anamnesis and physical examination. However, there are specific laboratory tests available. The diagnosis can be made based on one of the following signs or laboratory findings: Presence of urethral secretions; bacterioscopy by Gram staining of purulent secretions obtained through the urethral smear showing $\geq$ two polymorphonuclear leukocytes on an immersion slide; testing for leukocyte esterase and/ or presence of $\geq 10$ leukocytes per field in urinary sediment of the first urine. If these criteria are not present, the test for $\mathrm{N}$. gonorrheae and C. trachomatis may be conducted by Naat - Nucleic Acid Amplification Testing ${ }^{21}(\mathrm{~B})^{22}$ (D). In sexually active young patients who present pyuria without bacteriuria, there should be a strong suspicion of urethritis caused by C. trachomatis. In these cases, the laboratory test of choice is the Naat using first urine. In cases in which there is evidence of the presence of Gram-negative intracellular diplococcus in the bacterioscopy, the patient must be treated for gonorrhea, and the test of nucleic acid amplification for $C$. trachomatis must be performed, since the infections can coexist.

What are the laboratory diagnostic methods for identifying the etiologic agents of genital ulcers?

Genital erosive/aphthous lesions, although often associated with sexually transmitted infections in the sexually active population, may occur due to various conditions that include non-infectious causes, autoimmune diseases, inflammatory diseases, neoplasms, or even present an unknown cause. The causes that are not associated with sexually transmitted infections include infection by the Epstein-Barr virus, tuberculosis, leishmaniasis, cutaneous amebiasis. It is also possible to find an association to drug reactions, immunobullous diseases, aphthosis, Behcet's disease, inflammatory bowel disease, forms of erosive lichen planus and lichen sclerosus et atrophi- 
cus, pre-malignant and malignant conditions, pyoderma gangrenosum, and hidradenitis suppurativa ${ }^{23}$ (D). Among the infectious agents most commonly related to genital ulcers, we can highlight the infection by T. pallidum, herpes simplex virus types 1 and 2 (HSV-1 and HSV-2), Haemophilus ducreyi, Chlamydia trachomatis, and Klebsiella granulomatis, which may occur in isolation or in association in the same lesion.

Following, we will present methods for the diagnosis of the etiologic agents of infectious genital ulcers, except for those directed to the diagnosis of primary and secondary syphilis (already presented in a specific item of this guideline).

\section{GENITAL HERPES}

It is a genital infection caused by the herpes simplex virus (HSV) of types 1 and 2 of the Herpesviridae family. Although both may cause injuries to any part, there is a predominance of type 2 in genital lesions. The clinical manifestations of an HSV infection depend on the patient's characteristics, such as age, immunity, in addition to genetic predisposition, and can be divided into primary (more severe, with the onset of erythematous papular lesions that progress to vesicles, rich in infectious viral particles, usually painful and of variable location in the genital region) and recurrent (less intense symptoms, usually in the same location as the initial lesion and may be preceded by prodromes).

The diagnosis of the infection is made based on the clinical characteristics of the lesion, more specifically by identifying the vesicles characteristic of this infection, paired with laboratory confirmation. The scraping from the base of the ulcer targeting viral isolation with Giemsa Wright or hematoxylin and eosin (Tzanck method) staining is considered the gold standard for the diagnosis of HSV since it allows to observe viral inclusions; however, it requires freshly collected material, with the virus still viable, as well as a longer time to identify the virus. Serological tests specific for HSV are considered the second line when the culture and CRP methods are not available. The tests include immunofluorescence, immunoblot, western blot, and immunoassay (EIA) and can detect the antibodies against the glycoproteins of HSV. Some of these tests have the disadvantage of not providing quantitative results, in addition to making it impossible to distinguish from infections caused by HSV-1 and 2. In recent years, the use of molecular techniques has increased, such as real-time polymerase chain reaction, which presents faster implementation and is more sensitive for detecting the virus in both symptomatic and asymptomatic patients; therefore, it constitutes a technique for the detection and quantification of nucleic acids, in addition to being a reproducible method ${ }^{24.25}(\mathrm{D})$.

\section{LYMPHOGRANULOMA VENEREUM (LGV)}

LGV is a sexually transmitted infection caused by serovars L1, L2, or L3 of Chlamydia trachomatis ${ }^{26}$ (D). Typically, after the incubation period, it presents itself as a papule that may ulcerate at the site of inoculation. This stage often goes unnoticed by the patient, healing spontaneously. The inguinal adenomegaly develops weeks (two to six) after the initial lesion and is the most common clinical manifestation. The involvement of lymph nodes can evolve into abscesses with suppuration and fistulation by multiple holes (buboes). It can also manifest as proctitis or affect the anal region, resulting in fistulas and stenoses ${ }^{27}$ (D). In women, pelvic lymph nodes can be affected if the primary lesions occur in the cervix. In this case, the patient can present symptoms related to pelvic inflammatory disease ${ }^{27}(\mathrm{D})$.

The diagnosis of LGV is based on the clinical manifestations associated with the identification of Chlamydia trachomatis, by means of isolation in cell culture, serology, or tests of amplification of nucleic acids (Naat) in the material collected from urine and urethral and cervical swab. Some guidelines do not recommend the use of serological tests given the possible cross-reactions with other species of C. trachomatis, in addition to the difficulties in interpreting their title variations $^{28}(\mathrm{~B})^{29}(\mathrm{D})$. On the other hand, others recommend it as a measure to support the diagnosis in some contexts, for example, in the impossibility of performing the genotyping of C. trachomatis ${ }^{30.31}$ (D). The detection of DNA by CRP in urine or vaginal secretion sample presents high diagnosis accuracy, with values of sensitivity and specificity of $90 \%$ and $99 \%$, respectively ${ }^{32}$ (B). However, it has limited accuracy for extragenital sites.

\section{CHANCROID}

It is a STI caused by Haemophilus ducreyi. Also known as soft chancre, it presents itself in the form of ulcers on the genitals, often multiple, painful, with purulent exudate, and can be associated with suppurative inguinal lymphadenopathy ${ }^{33}$ (D). The diagnosis can be done with the use of light microscopy after 
Gram staining with visualization of small Gram-negative bacilli. Since direct microscopy has low accuracy, the definitive diagnosis is achieved by isolating the micro-organism in culture from the lymph node ulcer or aspirate. Molecular methods have high values of sensitivity and specificity for detecting $H$. ducreyi in comparison with the culture, which, at best, can reach a sensitivity of $75 \%{ }^{34}$ (B). However, so far there are no commercially available Naat ${ }^{35}(\mathrm{D})$. The humoral immune response to the $H$. ducreyi infection starts to develop as the disease progresses through the stage of ulceration. Thus, due to their low sensitivity, serological techniques have no place in the diagnosis of soft chancre in individuals with genital ulcers ${ }^{36}$ (B).

\section{DONOVANOSIS}

It is a chronic STI caused by the Gram-negative bacteria Klebsiella granulomatis. Also known as granuloma inguinale, it starts as a subcutaneous nodule or papule at the site of inoculation, leading to the formation of an ulcer with a well-defined edge ${ }^{37.38}$ (D). The ulceration evolves gradually and may become vegetative. New lesions can be formed by autoinoculation. Sometimes, the spread also results in cutaneous lesions in extragenital sites. The diagnosis is made by testing for corpuscles of Donovan, obtained by biopsy smear of the ulceration.

\section{What are the laboratory tests that identify} the various types of hpv and what is their importance in clinical practice?

The human papillomaviruses (HPV) are the most prevalent virus involved in STIs. They are composed by non-enveloped capsids that include dual and circular strands of DNA capable of infecting epithelial cells of mucosa and epidermis and may cause hyperplasic and neoplastic injuries. They belong to the Papillomarividae family, which comprises more than 200 types of viruses based on DNA sequence; they are numbered sequentially and classified into types of low and high risk, according to the oncogenic potential $^{39}$ (B). The viral genome has three regions: the regulatory region (LCR - long control region), made of genes that encode proteins involved in replication, transcription of the DNA, and cell transformation; early region ( $\mathrm{E}$ - early); and late region (L - late), formed by two genes, L1 and L2. The oncogenic potential involves mainly the early genes (E2, E6, and E7), whose proteins promote, among other activi- ties, the inactivation of tumor suppressor genes. The knowledge of the natural history of this infection is of fundamental importance for the understanding and use of diagnostic tests in clinical practice. Another point of great relevance is the understanding that the risk of an infection caused by a virus of low oncogenic potential, for example, is not the same as when the infection is caused by a high-risk $\operatorname{HPV}^{40}(\mathrm{~B})$.

HPV infections are extremely frequent and occur in the first decades after the beginning of sexual life with high prevalence among young women. It is often transient (prevalence decreases with age - in women between 20 and 24 years and between 24 and 29 years, there is a prevalence of $13 \%$ and $17 \%$, respectively, which drops to $4.3 \%$ after the age of 30 years $)^{41.42}$ (B). In most cases, the infection presents no clinical manifestations, with a viral whitening. On the other hand, in some cases, the infection becomes persistent and promotes cell proliferation induced by some specific types of HPV, which can cause, when the concomitant with other important factors for the carcinogenic process, the emergence of neoplasms. Cervical cancer screening may eventually identify cellular changes associated with the HPV infection; however, its low sensitivity indicates the need for complimentary testing to identify viral infection. Molecular tests to identify HPV are being rapidly introduced in cervical cancer screening since they can provide both diagnostic and prognostic information. Technical advances directed at identifying the DNA of HPV are in constant development since several of these tests are still in the process of clinical validation. Usually, the infection can be confirmed by molecular tests that detect HPV-DNA, such as hybrid capture, in situ hybridization, and CRP, the latter being the most widely used in HPV research and typing. CRP has high sensitivity and specificity, and when associated with the analysis of extension polymorphism of DNA fragments, it can detect more than one type of HPV. This method can be used in the primary screening of women with an infection caused by high-risk viral types. However, it should not be used for cervical cancer screening in young women (younger than 25-30 years) due to the low positive predictive value (high prevalence of infection in this population $)^{43}(\mathrm{~B})$. Numerous studies have provided evidence supporting its use as a screening test, in the evaluation of indeterminate findings on cytology, and in the follow-up after a positive screening, but with no altered anatomopathological results and 
as a test for follow-up assessment. It is important to emphasize that the data obtained from clinical studies vary depending on the HPV test used and there is also variation among laboratories. In other words, each test has its own values of accuracy for identifying high-grade intraepithelial lesions. Next, we will present aspects related to cervical cancer screening.

\section{CERVICAL CANCER SCREENING}

The main guidelines for cervical cancer screening programs vary worldwide due to differences in the availability of resources to finance appropriate measures of public health. Many countries use a cervical cancer screening program based on the Pap smear. However, new recommendations have encouraged the use of the HPV-DNA testing in the screening, with estimates of over $30 \%$ of reduction of cervical cancer among women aged 25-64 years ${ }^{44}$ (B). The strengths in the use of HPV-DNA tests are supported by objective qualitative and/or quantitative results, reproducibility and high negative predictive capacity $^{45.46}$ (B). A systematic review with meta-analysis confirmed the high sensitivity but with a lower specificity of the HPV-DNA testing in comparison with the Pap smear ${ }^{47}$ (A). In this review, in spite of the high heterogeneity among the studies, the sensitivity values for identifying high-grade intraepithelial lesions (CIN2 and CIN3) were 1.37 (95\% CI: 1.22 to 1.54 ) and 1.43 (IC95\%: 1.15 to 1.77 ), respectively.

The high negative predictive value of HPV-DNA tests allow for a better monitoring of women tested negative for HPV, since the development of cervical cancer in the next five to ten years is unlikely, allowing, thus, longer intervals between the screenings (B). In addition, the negative test for HPV also allows returning to screening with the Pap smear even after abnormal test results or after treatment.

\section{SYNTHESIS OF EVIDENCE}

The laboratory diagnosis of a T. pallidum infection is based on clinical evaluation, detection, and identification of the etiologic agent. The different types of serological tests are usually grouped according to their use in tests for screening, confirmation, and monitoring of treatment. This form of grouping is a result of the different antibodies researched, the accuracy, onset and duration of their reactivity, as well as maintenance or not this reactivity after therapy.
Infectious urethritis is caused by sexually transmissible pathogens. There should be clinical suspicion in cases of sexually active individuals with complaints of dysuria, urethral pruritus and/or urethral discharge. The diagnosis can be confirmed by the presence of one of the following findings: urethral secretions; bacterioscopy by Gram staining of purulent secretions obtained through the urethral smear showing $\geq$ two polymorphonuclear leukocytes on an immersion slide; testing for leukocyte esterase and/ or presence of $\geq 10$ leukocytes per field in the urinary sediment of the first urine.

Genital ulcers may be classified into STIs and nonSTIs. Among those caused by STIs, there are syphilis, chancroid, donovanosis, lymphogranuloma venereum, and genital herpes. Syphilis usually presents as a chancre, a single, painless, hardened, clean bottom ulcer, and is caused by Treponema pallidum. The diagnosis is made by visualization of the T. pallidum in darkfield microscopy and by treponemal and nontreponemal serological. Chancroid is caused by Haemophyllus ducrey, and its characteristic is the presence of very painful ulcers with dirty bottom, jagged edges and accompanied or not by lymphadenopathy. The visualization of small Gram-negative bacilli from the culture is attempted as a diagnostic test. Clinically, the lymphogranuloma venereum presents itself as a papule that progresses to a scab and subsequently an ulcer. The disease can manifest in other areas, such as the rectum, causing proctitis. The diagnosis is usually clinical and confirmed by direct immunofluorescence and monoclonal antigens for Chlamydia trachomatis. Donovanosis is caused by Klebsiella granulomatis and is characterized by the presence of vegetative ulcers. The diagnosis is clinical and supported by the visualization of bacilli in the interior of histiocytes when stained by Giemsa. Most people infected by HSV-1 and 2 never present clinical signs, but some may have recurrent genital lesions. The diagnosis is essentially clinical, but it can also be done by cytodiagnosis. There are tests with monoclonal antibodies to differentiate HSV-1 and HSV-2, with results in up to two days after infection, as well as techniques of CRP.

The cervical cancer screening strategy includes the Pap smear, HPV-DNA test, and different combinations of pap smear and HPV-DNA. The choice of the type of test depends on the resources available, age, and risk factors of the individual. The HPV-DNA test presents high sensitivity in comparison to the Pap smear for high-grade intraepithelial lesions. 


\section{ANNEX I}

\section{Clinical question}

- What are the tests used for the diagnosis of syphilis?

- How are the rapid tests conducted for the diagnosis of syphilis?

- What are the laboratory diagnostic methods for urethritis?

- What are the laboratory diagnostic methods for identifying the etiologic agents of genital ulcers?

- What are the laboratory tests that identify the various types of HPV and what is their importance in clinical practice?

\section{Structured clinical question}

\begin{tabular}{|l|l|}
\hline $\mathbf{P}$ & $\begin{array}{l}\text { Syphilis OR Urethritis OR Ulcer OR Chlamydia } \\
\text { Infections OR Lymphogranuloma Venereum OR Herpes } \\
\text { Simplex OR Genital Herpes Simplex OR Haemophilus } \\
\text { ducreyi OR Granuloma Inguinale OR Donovanosis OR } \\
\text { Calymmatobacterium OR Papillomavirus Infections OR HPV } \\
\text { Infections OR Human Papillomavirus Infection }\end{array}$ \\
\hline $\mathbf{I}$ & $\begin{array}{l}\text { Serologic Tests OR Serodiagnoses OR Syphilis Serodiagnosis } \\
\text { OR Fluorescent Treponemal Antibody-Absorption Test } \\
\text { OR FTA ABS Test OR Treponema Immobilization Test } \\
\text { OR Treponema Immobilization Tests OR Immobilization } \\
\text { Test, Treponema OR Fluorescent Antibody Technique OR } \\
\text { Human Papillomavirus DNA Tests OR HPV DNA Tests OR } \\
\text { Molecular Diagnostic Techniques OR Cytological Techniques }\end{array}$ \\
\hline C & Does not apply \\
\hline $\mathbf{O}$ & Diagnosis \\
\hline
\end{tabular}

\section{Inclusion criteria for the selected papers}

The selection of the studies and the evaluation of the titles and abstracts obtained from the search strategy in the database consulted were independently and blindly conducted by two researchers in accordance with the inclusion and exclusion criteria established and described in the PICO. Finally, studies with potential relevance were separated.

\section{According to the design of the studies}

We included in our evaluation systematic reviews with meta-analysis of randomized clinical trials, and before and after studies.

\section{Language}

We included studies available without restriction to the language.

\section{According to publication}

Only studies with texts available in its entirety were considered for critical evaluation.

\section{SEARCH FOR PAPERS}

\section{Database}

The scientific database consulted was Medline (via PubMed) and manual search.

\section{Research strategy}

(Syphilis OR Urethritis OR Ulcer OR Chlamydia Infections OR Lymphogranuloma Venereum OR Herpes Simplex OR Genital Herpes Simplex OR Haemophilus ducreyi OR Granuloma Inguinale OR Donovanosis OR Calymmatobacterium OR Papillomavirus Infections OR HPV Infections OR Human Papillomavirus Infection) AND (Serologic Tests OR Serodiagnoses OR Syphilis Serodiagnosis OR Fluorescent Treponemal Antibody-Absorption Test OR FTA ABS Test OR Treponema Immobilization Test OR Treponema Immobilization Tests OR Immobilization Test, Treponema OR Fluorescent Antibody Technique OR Human Papillomavirus DNA Tests OR HPV DNA Tests OR Molecular Diagnostic Techniques OR Cytological Techniques).

Manual search - Reference of references, review, and guidelines.

\section{CRITICAL EVALUATION \\ Relevance - clinical importance}

This guideline was prepared by means of a clinically relevant question in order to gather information in medicine to standardize approaches and assist in decision-making.

\section{Reliability - Internal validity}

The selection of the studies and the evaluation of the titles and abstracts obtained from the search strategy in the databases consulted were independently and blindly conducted, in total accordance with the inclusion and exclusion criteria. Finally, studies with potential relevance were separated. When the title and the summary were not enlightening, we sought for the full article. Only studies with texts available in its entirety were considered for critical evaluation. 


\section{RESULTS APPLICATION - EXTERNAL VALIDITY}

The level of scientific evidence was classified by type of study according to Oxford ${ }^{49}$ (Table 1).

TABLE 1- GRADES FOR RECOMMENDATION AND LEVEL OF EVIDENCE

A: Experimental or observational studies of higher consistency.

B: Experimental or observational studies of lower consistency.

C: Uncontrolled case/study reports.

D: Opinion deprived of critical evaluation, based on consensus, physiological studies or animal models.

The selected evidence was defined as a randomized controlled clinical trial (RCT) and submitted to an appropriate critical evaluation checklist (Table 2). The critical evaluation of RCT allows to classify it according to the Jadad score ${ }^{50}$, considering Jadad trials $<$ three (3) as inconsistent (grade B) and those with score $\geq$ three (3) consistent (grade A), and according to the Grade score (strong or moderate evidence).

When the evidence selected was defined as a comparative study (observational cohorts, or non-randomized clinical trial), it was subjected to an adequate critical assessment- (Table 3), allowing for the classification of the study according to the Newcastle Ottawa ScaleE ${ }^{52}$, which considered consistent cohort studies with scores $\geq 6$, and inconsistent $<6$.

TABLE 2 - GUIDE FOR CRITICAL EVALUATION OF RANDOMIZED CONTROLLED TRIALS

\begin{tabular}{|l|l|}
\hline $\begin{array}{l}\text { Study data - Reference, study } \\
\text { design, Jadad, level of evidence }\end{array}$ & $\begin{array}{l}\text { Sample size calculation - } \\
\text { Estimated differences, power, } \\
\text { significance level, the total } \\
\text { number of patients }\end{array}$ \\
\hline $\begin{array}{l}\text { Patient selection - Inclusion } \\
\text { and exclusion criteria }\end{array}$ & $\begin{array}{l}\text { Patients - Recruited, } \\
\text { randomized, prognostic } \\
\text { differences }\end{array}$ \\
\hline $\begin{array}{l}\text { Randomization - Description } \\
\text { and blinded allocation }\end{array}$ & $\begin{array}{l}\text { Patient follow-up - Time, } \\
\text { losses, migration }\end{array}$ \\
\hline $\begin{array}{l}\text { Treatment protocol - } \\
\text { Intervention, control, and } \\
\text { blinding }\end{array}$ & $\begin{array}{l}\text { Analysis - Intention to treat, } \\
\text { analyzed intervention and } \\
\text { control }\end{array}$ \\
\hline $\begin{array}{l}\text { Outcomes considered } \\
\text { - Primary, secondary, } \\
\text { measurement instrument for } \\
\text { the outcome of interest }\end{array}$ & $\begin{array}{l}\text { Results - Benefits or harmful } \\
\text { effects in absolute data, benefits } \\
\text { or harmful effects on average }\end{array}$ \\
\hline
\end{tabular}

\section{METHOD OF EXTRACTION AND RESULT ANALYSIS}

For results with available evidence, the population, intervention, outcomes, presence or absence of benefits and/or harmful effects, and controversy will be specifically defined whenever possible.

The results will be presented preferably in absolute data, absolute risk, the number needed to treat (NNT) or number needed to harm (NNH) and, eventually, in mean and standard deviation values (Table 4)

TABLE 4 - WORKSHEET USED FOR DESCRIBING AND PRESENTING THE RESULTS FOR EACH STUDY

\begin{tabular}{|l|}
\hline Evidence included \\
\hline Study design \\
\hline Selected population \\
\hline Follow-up time \\
\hline Outcomes considered \\
\hline Expression of results: percentage, risk, odds, hazard ratio, mean \\
\hline
\end{tabular}

\section{APPLICATION OF EVIDENCE - RECOMMENDATION}

The recommendations will be elaborated by the authors of the review, with the initial characteristic of synthesis of evidence subject to validation by all authors who participated in creating the Guideline.

The global synthesis will be based on the evidence described. Its strength will be estimated (Oxford ${ }^{49}$ / Grade $^{51}$ ) as $1 \mathrm{~b}$ and $1 \mathrm{c}$ (grade A) or strong, and as 2a, $2 \mathrm{~b}$ and $2 \mathrm{c}$ (grade B) or moderate weak, or very weak.

\section{CONFLICT OF INTEREST}

There is no conflict of interest related to this review that can be declared by any of the authors.

\section{FINAL DECLARATION}

The Guidelines Project, an initiative of the Brazilian Medical Association in partnership with the Specialty Societies, aims to reconcile medical information

TABLE 3 - GUIDE FOR CRITICAL EVALUATION OF COHORT STUDIES

\begin{tabular}{|c|c|c|c|c|c|c|}
\hline $\begin{array}{l}\text { Representativeness } \\
\text { of the exposed and } \\
\text { selection of the non- } \\
\text { exposed } \\
\text { (Max. } 2 \text { points) }\end{array}$ & $\begin{array}{l}\text { Exposure } \\
\text { definition } \\
\text { (Max. } 1 \text { point) }\end{array}$ & $\begin{array}{l}\text { Demonstration } \\
\text { that the outcome } \\
\text { of interest was } \\
\text { not present at the } \\
\text { beginning of the } \\
\text { study } \\
\text { (Max. } 1 \text { point) }\end{array}$ & $\begin{array}{l}\text { Comparability based } \\
\text { on the design or the } \\
\text { analysis } \\
\text { (Max. } 2 \text { points) }\end{array}$ & $\begin{array}{l}\text { Outcome } \\
\text { assessment } \\
\text { (Max. } 1 \text { point) }\end{array}$ & $\begin{array}{l}\text { Adequate } \\
\text { follow-up time } \\
\text { (Max. } 2 \text { points) }\end{array}$ & $\begin{array}{l}\text { Scores and } \\
\text { level of } \\
\text { evidence }\end{array}$ \\
\hline
\end{tabular}


in order to standardize approaches that can aid the physician's reasoning and decision-making process. The information contained in this project must be sub- mitted to the evaluation and criticism of the physician responsible for the conduct to be followed given the reality and clinical condition of each patient.

\section{REFERENCES}

1. Gayet-Ageron $A$, Lautenschlager $S$, Ninet B, Perneger TV, Combescure C. Sensitivity, specificity and likelihood ratios of PCR in the diagnosis of syphilis: a systematic review and meta-analysis. Sex Transm Infect. 2013;89(3):251-6. PubMed PMID: 23024223.

2. Buffet M, Grange PA, Gerhardt $P$, Carlotti $A$, Calvez V, Bianchi A, Dupin N. Diagnosing Treponema pallidum in secondary syphilis by PCR and immunohistochemistry. J Invest Dermatol. 2007;127(10):2345-50. PubMed PMID: 17554371

3. Romanowski B, Forsey E, Prasad E, Lukehart S, Tam M, Hook EW 3rd. Detection of Treponema pallidum by a fluorescent monoclonal antibody test. Sex Transm Dis. 1987;14(3):156-9. PubMed PMID: 3310278.

4. Gayet-Ageron A, Lautenschlager S, Ninet B, Perneger TV, Combescure C. Sensitivity, specificity and likelihood ratios of PCR in the diagnosis of syphilis: a systematic review and meta-analysis. Sex Transm Infect. 2013;89(3):251-6. PubMed PMID: 23024223.

5. Brown ST, Zaidi A, Larsen SA, Reynolds GH. Serological response to syphilis treatment. A new analysis of old data. JAMA. 1985;253(9):1296-9. PubMed PMID: 3155812.

6. Romanowski B, Sutherland R, Fick GH, Mooney D, Love E). Serologic response to treatment of infectious syphilis. Ann Intern Med. 1991;114(12):1005-9. PubMed PMID: 2029095.

7. Larsen $\mathrm{SA}$, Steiner $\mathrm{BM}$, Rudolph $\mathrm{AH}$. Laboratory diagnosis and interpretation of tests for syphilis. Clin Microbiol Rev. 1995;8(1):1-21. Review. PubMed PMID: 7704889

8. Creegan L, Bauer HM, Samuel MC, Klausner J, Liska S, Bolan G. An evaluation of the relative sensitivities of the venereal disease research laboratory test and the Treponema pallidum particle agglutination test among patients diagnosed with primary syphilis. Sex Transm Dis. 2007;34(12):1016-1018. PubMed PMID: 18080352.

9. Fiumara NJ. Posttreatment serological response of biologic false-positive reactors. JAMA. 1982;247(6):817-8. PubMed PMID: 7057562.

10. Pastuszczak M, Gozdzialska A, Jakiela B, Obtulowicz A, Jaskiewicz |, Wojas-Pelc A. Robust pro-inflammatory immune response is associated with serological cure in patients with syphilis: an observational study. Sex Transm Infect. 2017;93(1):11-14. PubMed PMID: 27356549.

11. Sambri V, Marangoni A, Eyer C, Reichhuber C, Soutschek E, Negosanti M, D'Antuono A, Cevenini R. Western immunoblotting with five Treponema pallidum recombinant antigens for serologic diagnosis of syphilis. Clin Diagn Lab Immunol. 2001;8(3):534-9. PubMed PMID: 11329453.

12. Wong EH, Klausner JD, Caguin-Grygiel G, Madayag C, Barber KO, Qiu J, Liska S, Pandori MW. Evaluation of an IgM/lgG sensitive enzyme immunoassay and the utility of index values for the screening of syphilis infection in a high-risk population. Sex Transm Dis. 2011;38(6):528-32. PubMed PMID: 21233789.

13. Peeling RW, Holmes KK, Mabey D, Ronald A. Rapid tests for sexually transmitted infections (STIs): the way forward. Sex Transm Infect. 2006;82 Suppl 5:v1-6. PubMed PMID: 17151023.

14. Bronzan RN, Mwesigwa-Kayongo DC, Narkunas D, Schmid GP, Neilsen GA, Ballard RC, Karuhije P, Ddamba I, Nombekela E, Hoyi G, Dlali P, Makwedini N, Fehler HG, Blandford JM, Ryan C. On-site rapid antenatal syphilis screening with na immunochromatographic strip improves case detection and treatment in rural South African clinics. Sex Transm Dis. 2007;34(7 Suppl):S55-60. PubMed PMID: 17139234

15. Rydzak CE, Goldie S). Cost-effectiveness of rapid point-of-care prenatal syphilis screening in sub-Saharan Africa. Sex Transm Dis. 2008;35(9):77584. PubMed PMID: 18607319

16. Phang Romero Casas C, Martyn-St James M, Hamilton J, Marinho DS, Castro R, Harnan S. Rapid diagnostic test for antenatal syphilis screening in low-income and middle-income countries: a systematic review and meta-analysis. BMI Open. 2018;8(2):e018132. PubMed PMID: 29467132.
17. Causer LM, Kaldor JM, Fairley CK, Donovan B, Karapanagiotidis T, Leslie DE, Robertson PW, McNulty AM, Anderson D, Wand H, Conway DP, Denham I, Ryan C, Guy RJ. A laboratory-based evaluation of four rapid point-of-care tests for syphilis. PLoS One. 2014;9(3):e91504. PubMed PMID: 24618681.

18. Gomez GB, Kamb ML, Newman LM, Mark |, Broutet N, Hawkes S|. Untreated maternal syphilis and adverse outcomes of pregnancy: a systematic review and meta-analysis. Bull World Health Organ. 2013;91(3):217-26. PubMed PMID: 23476094.

19. Yin $Y P$, Chen XS, Wei WH, Gong KL, Cao WL, Yong G, Feng L, Huang SI, Wang DM, Han Y, Chen SC, Mabey D, Peeling RW. A dual point-of-care test shows good performance in simultaneously detecting nontreponemal and treponemal antibodies in patients with syphilis: a multisite evaluation study in China. Clin Infect Dis. 2013;56(5):659-65. PubMed PMID: 23132172.

20. Bradshaw CS, Tabrizi SN, Read TR, Garland SM, Hopkins CA, Moss LM, Fairley CK. Etiologies of nongonococcal urethritis: bacteria, viruses, and the association with orogenital exposure. J Infect Dis. 2006;193(3):336-45. PubMed PMID: 16388480.

21. Geisler WM, Yu S, Hook EW 3rd. Chlamydial and gonococcal infection in men without polymorphonuclear leukocytes on gram stain: implications for diagnostic approach and management. Sex Transm Dis. 2005;32(10):630-4. PubMed PMID: 16205305.

22. Workowski KA. Centers for Disease Control and Prevention Sexually Transmitted Diseases Treatment Guidelines. Clin Infect Dis. 2015;61 Suppl 8:S759-62. PubMed PMID: 26602614.

23. Bohl TG. Vulvar ulcers and erosions--a dermatologist's viewpoint. Dermatol Ther. 2004;17(1):55-67. Review. PubMed PMID: 14756892.

24. Ratnam S, Severini A, Zahariadis G, Petric M, Romanowski B. The diagnosis of genital herpes - beyond culture: An evidence-based guide for the utilization of polymerase chain reaction and herpes simplex virus type-specific serology. Can | Infect Dis Med Microbiol. 2007;18(4):233-40. PubMed PMID: 18923735

25. Kawada J, Kimura H, Ito Y, Hoshino Y, Tanaka-Kitajima N, Ando Y, Futamura M, Morishima T. Comparison of real-time and nested PCR assays for detection of herpes simplex virus DNA. Microbiol Immunol. 2004;48(5):411-5. PubMed PMID: 15215628.

26. Piñeiro L, Galán IC, Vall-Mayans M. Infections caused by Chlamydia trachomatis (including lymphogranuloma venereum) and Mycoplasma genitalium. Enferm Infecc Microbiol Clin. 2019. pii: S0213-005X(19)30131-4. PubMed PMID: 30878312

27. Rawla P, Limaiem F. Lymphogranuloma Venereum. 2019 Feb 13. StatPearls [Internet]. Treasure Island (FL): StatPearls Publishing; 2019. Available from http://www.ncbi.nlm.nih.gov/books/NBK537362/ PubMed PMID: 30726047.

28. Schachter |. Confirmatory serodiagnosis of lymphogranuloma venereum proctitis may yield false-positive results due to other chlamydial infections of the rectum. Sex Transm Dis. 1981;8(1):26-8. PubMed PMID: 7221807.

29. Public Health Agency of Canada. Supplementary statement concerning the laboratory diagnosis of lymphogranuloma venereum (LGV) Ottawa, ON: Public Health Agency of Canada; 2014. Available from: www.phac-aspc.gc.ca/std-mts/sti-its/cgsti-ldcits/assets/pdf/appendix-supp-lgv-eng. pdf. Acessado em 27 de maio de 2019.

30. White I, O'Farrell N, Daniels D; British Association for Sexual Health and HIV. 2013 UK National Guideline for the management of lymphogranuloma venereum: Clinical Effectiveness Group of the British Association for Sexual Health and HIV (CEG/BASHH) Guideline development group. Int J STD AIDS. 2013:24(8):593-601. PubMed PMID: 23970591

31. Workowski KA, Bolan GA; Centers for Disease Control and Preven- 
tion. Sexually transmitted diseases treatment guidelines, 2015. MMWR Recomm Rep. 2015;64(RR-03):1-137. PubMed PMID: 26042815.

32. Pasternack R, Vuorinen P, Pitkäjärvi T, Koskela M, Miettinen A. Comparison of manual Amplicor PCR, Cobas Amplicor PCR, and LCx assays for detection of Chlamydia trachomatis infection in women by using urine specimens. J Clin Microbiol. 1997;35(2):402-5. PubMed PMID: 9003605.

33. Lewis DA. Epidemiology, clinical features, diagnosis and treatment of Haemophilus ducreyi - a disappearing pathogen? Expert Rev Anti Infect Ther. 2014;12(6):687-96. PubMed PMID: 24597521.

34. Morse SA, Trees DL, Htun Y, Radebe F, Orle KA, Dangor Y, Beck-Sague CM, Schmid S, Fehler G, Weiss JB, Ballard RC. Comparison of clinical diagnosis and standard laboratory and molecular methods for the diagnosis of genital ulcer disease in Lesotho: association with human immunodeficiency virus infection. I Infect Dis. 1997;175(3):583-9. PubMed PMID: 9041329.

35. Alfa M. The laboratory diagnosis of Haemophilus ducreyi. Can I Infect Dis Med Microbiol. 2005;16(1):31-4. PubMed PMID: 18159525.

36. Totten PA, Kuypers JM, Chen CY, Alfa MJ, Parsons LM, Dutro SM, Morse SA, Kiviat NB. Etiology of genital ulcer disease in Dakar, Senegal, and comparison of PCR and serologic assays for detection of Haemophilus ducreyi. J Clin Microbiol. 2000;38(1):268-73. PubMed PMID: 10618099.

37. O'Farrell N. Donovanosis. Sex Transm Infect. 2002;78(6):452-7. Review. PubMed PMID: 12473810

38. O'Farrell N, Hoosen A, Kingston M. 2018 UK national guideline for the management of donovanosis. Int I STD AIDS. 2018;29(10):946-948. PubMed PMID: 29743002

39. Muñoz N, Bosch FX, de Sanjosé S, Herrero R, Castellsagué X, Shah KV, Snijders PJ, Meijer C); International Agency for Research on Cancer Multicenter Cervical Cancer Study Group. Epidemiologic classification of human papillomavirus types associated with cervical cancer. N Engl | Med. 2003;348(6):518-27. PubMed PMID: 12571259.

40. Prétet JL, Jacquard AC, Carcopino X, Charlot JF, Bouhour D, Kantelip B, Soubeyrand B, Leocmach Y, Mougin C, Riethmuller D; EDITH study group. Human papillomavirus (HPV) genotype distribution in invasive cervical cancers in France: EDITH study. Int J Cancer. 2008;122(2):428-32. PubMed PMID: 17893882.

41. Winer RL, Feng Q, Hughes IP, O'Reilly S, Kiviat NB, Koutsky LA. Risk of female human papillomavirus acquisition associated with first male sex partner. / Infect Dis. 2008;197(2):279-82. PubMed PMID: 18179386.

42. Jacobs MV, Walboomers JM, Snijders PJ, Voorhorst FJ, Verheijen RH, Fransen-Daalmeijer N, Meijer C). Distribution of 37 mucosotropic HPV types in women with cytologically normal cervical smears: the age-related patterns for high-risk and low-risk types. Int J Cancer. 2000;87(2):221-7. PubMed PMID: 10861478.
43. Wright TC Ir, Stoler MH, Sharma A, Zhang G, Behrens C, Wright TL; ATHENA (Addressing THE Need for Advanced HPV Diagnostics) Study Group. Evaluation of HPV-16 and HPV-18 genotyping for the triage of women with high-risk HPV+ cytology-negative results. Am | Clin Pathol. 2011;136(4):578-86. PubMed PMID: 21917680

44. Castanon A, Landy R, Sasieni P. By how much could screening by primary human papillomavirus testing reduce cervical cancer incidence in England? ) Med Screen. 2017;24(2):110-112. PubMed PMID: 27363972.

45. Kitchener HC Gilham $C$, Sargent $A$, Bailey A, Albrow R, Roberts $C$, Desai M, Mather J, Turner A, Moss S, Peto J. A comparison of HPV DNA testing and liquid based cytology over three rounds of primary cervical screening: extended follow up in the ARTISTIC trial. Eur | Cancer. 2011;47(6):864-71. PubMed PMID: 21334200

46. Naucler $P$, Ryd W, Törnberg $S$, Strand A, Wadell G, Elfgren K, Rådberg T, Strander B, Forslund O, Hansson BG, Hagmar B, Johansson B, Rylander E, Dillner |. Efficacy of HPV DNA testing with cytology triage and/or repeat HPV DNA testing in primary cervical cancer screening. I Natl Cancer Inst. 2009;101(2):88-99. PubMed PMID: 19141778.

47. Arbyn M, Ronco G, Anttila A, Meijer C), Poljak M, Ogilvie G, Koliopoulos G, Naucler P, Sankaranarayanan R, Peto |. Evidence regarding human papillomavirus testing in secondary prevention of cervical cancer. Vaccine. 2012;30 Suppl 5:F88-99. PubMed PMID: 23199969.

48. Mesher D, Szarewski A, Cadman L, Cubie H, Kitchener $H$, Luesley D, Menon U, Hulman G, Desai M, Ho L, Terry G, Williams A, Sasieni P, Cuzick |. Long-term follow-up of cervical disease in women screened by cytology and HPV testing: results from the HART study. $\mathrm{Br}$ | Cancer. 2010;102(9):1405-10. PubMed PMID: 20354519.

49. Levels of Evidence and Grades of Recommendations - Oxford Centre for Evidence Based Medicine. Disponível em URL: http://cebm.jr2.ox.ac.uk/ docs/ old_levels. Htm

50. Jadad AR, Moore RA, Carroll D, Jenkinson C, Reynolds DJ, Gavaghan DJ, et al. Assessing the quality of reports of randomized clinical trials: is blinding necessary? Control Clin Trials 1996; 17:1-12.

51. Goldet G, Howick |. Understanding GRADE: an introduction. | Evid Based Med. 2013;6:50-54. PMID: 23557528

52. Wells GA, Shea B, O'Connell D, Peterson I, Welch V, et al.. (2011) The Newcastle-Ottawa Scale (NOS) for assessing the quality of nonrandomized studies in meta-analysis. Available at: www.ohri.ca/programs/clinical_epidemiology/oxford.asp (Accessed 04 March 2019).

53. Ball C, Sackett D, Phillips B, Haynes B, Straus S. Levels of evidence and grades of recommendations. In: EBM (Web site of the Oxford Centre for Evidence-Based Medicine). Available at: https://www.cebm. net/2009/06/oxford-centre-evidence-based-medicine-levels-evidence-march-2009/ (Accessed 04 March 2019). 